\title{
The feeding of young anthropoid apes
}

By Beryl D. Corner, Bristol Royal Hospital for Sick Children, St Michael's Hill, Bristol BS2 $8 B \mathcal{F}$

Since 1957 I have assisted Bristol Zoo to rear baby apes of the three species closest to man. These include one hand-reared chimpanzee in the hospital premature baby unit, weight $\mathrm{I} \cdot 22 \mathrm{~kg}$, two mother-reared chimpanzees, two sibling Sumatran orang-utans, the first being hand-reared, weight $\mathrm{I}^{\cdot} 95 \mathrm{~kg}$, a mother-reared Bornean orang-utan, and a gorilla.

Psychological factors are as important as physical ones for successful rearing of baby apes in captivity. Deprivation of mothering experience in infancy results in failure to develop adult sexual behaviour, so mother-rearing is the desired objective to enable Zoos to breed these rare animals.

They develop close relationships with their keepers and exhibit affection, jealousy, rage, and fear, and resent transfer to other staff. They easily become bored and enjoy entertaining zoo visitors. Thus successful mother-rearing demands constant attention by the keeper to prevent boredom, and sensitivity to the mother's mood and demands. The primiparous mother is usually young. In captivity she has had no opportunity to see mothering, so that immediate rejection of the baby is usual following the discomfort of birth, or she may not permit adequate breast feeding, necessitating separation in a few days.

The problems of artificial feeding are similar to those encountered with human infants; apes are susceptible to human diseases, so that unless staff are well trained in the prevention of infection the risk of gastroenteritis and pneumonia is high. The criteria of adequate nutrition are not precisely defined but steady growth, good muscle development, normal faeces, satisfactory dentition, avoidance of obesity and clinical signs of diet deficiencies, and a happy, vigorous baby were the criteria used as in human clinical paediatrics. Owing to its rarity, and the closest similarity to man, the feeding of the gorilla would seem to be most suitable for comparison.

Delilah and Sampson were 9-year-old, unrelated Lowland gorillas (Gorilla gorilla gorilla) who had been in Bristol Zoo for nearly 7 years. The first pregnancy resulted in a male birth, Daniel, on 10 April 1971, the first surviving gorilla birth in Britain. The rate of maternal rejection and 'baby battering' is very high in primiparous gorillas, but mother-rearing was achieved with great skill by the zoo staff.

Sampson was removed at the onset of labour, which was observed throughout. The baby cried at once: Delilah immediately picked him up with both hands and held him ventral-to-ventral against her chest with his head against the left side of her neck. She licked his face and at $3 \mathrm{~min}$ he opened his mouth and moved one arm. 
He was unable to support his head, and attempted to grasp her fur weakly. Weight was estimated at approximately $2 \mathrm{~kg}$.

Delilah's problems of boredom and loneliness were overcome by the keeper's constant attention, sitting by her. For $5 \mathrm{~d}$ she ate and drank very little and lay supine with Daniel lying ventral or dorsal on her abdomen, or sat holding him in the crook of her left arm. Her left hand always covered his body. She looked at him frequently and occasionally licked his face, hands and anogenital region. At $6 \mathrm{~h}$ after birth he sucked for $30 \mathrm{~s}$ from the left breast, and twice more for 30 and $60 \mathrm{~s}$ in the first $24 \mathrm{~h}$. Meconium was passed once just before $48 \mathrm{~h}$. Daniel moved very little and his grasp was not strong enough to pull him towards the breast; ability to reach the nipple seemed to depend on whether his head could flop near enough. Although Delilah never appeared to assist feeding, as soon as he started sucking she usually lay supine. On the 4 th day the left breast filled well and sucking time was 20-60 $\mathrm{s}$ at irregular intervals, the longest in the day being $\mathrm{I} \cdot 5 \mathrm{~h}$. Milk was seen to squirt once from the right breast but sucking there was only observed three times in the first 6 months. Delilah was seen to withdraw the right nipple from him, but she always permitted sucking on the left breast. The second defaecation, soft yellow faeces, was on the $5^{\text {th }}$ day. By the $7^{\text {th }}$ day Daniel was more alert, with open eyes, and was sucking for $2-6 \mathrm{~min}$ at intervals of $\mathrm{I}_{-1} \mathrm{I}_{5} \mathrm{~h}$. At $\mathrm{I} 4 \mathrm{~d}$, head control had improved and he began to look round.

During the next 2 weeks Delilah appeared to play with him occasionally. She moved him to lie between her legs on his back, or along her arm. Then she started training him to separate from her. He invariably cried but she picked him up at once and allowed him to suckle for comfort for a few seconds. By 5 weeks she generally climbed onto her warm sleeping slab to feed him and afterwards placed him prone on the slab to sleep. He cried loudly immediately on waking and she always rushed to pick him up; the usual sucking times were $\mathrm{I} \cdot 5-4 \mathrm{~min}$, and intervals from $2-3 \mathrm{~h}$. At night he lay on her abdomen and was usually seen to be sucking as he went to sleep. Soft yellow faeces were passed once daily.

At 9 weeks. Two samples of milk expressed from the left breast $\mathrm{I} h$ after feeding were analysed. They had the following composition $(\mathrm{g} / 1)$ : protein $\mathrm{I} 2$ and $\mathrm{I} 2$, and fat 8 and II. 'Two lower incisor teeth had erupted.

At 10 weeks. A medical examination was performed, and the following measurements were made: weight $3.572 \mathrm{~kg}$; head circumference $340 \mathrm{~mm}$; crown-rump length $340 \mathrm{~mm}$; arm length $220 \mathrm{~mm}$; leg length $225 \mathrm{~mm}$; hand length I00 $\mathrm{mm}$; fontanelle just open. The infant was crawling on forearms and knees, and picking up with his mouth small pieces of food left on the floor. Cheese, hard-boiled egg, orange and meat were selected. Breast feeding continued four times during the day for an average time of 2 min from the left breast, and at night. Delilah developed a severe coryza and bronchitis.

$A t$ I I weeks. Two central upper incisors erupted. Supplementary cup and spoon feeds started with $60 \mathrm{ml}$ SMA formula (John Wyeth Ltd, Maidenhead, Berks.), with ro ml Farex (Glaxo Ltd, Greenford, Middx), and Heinz bone and vegetable broth (H. J. Heinz Ltd, Hayes, Middx) with 60-120 ml SMA each once daily; 
Abidec (Parke, Davis \& Co. Ltd, Hounslow, Middx), three drops daily, was also given. Delilah was shown and allowed to taste these foods and always watched the procedure.

At 5 months. He started to hand-feed himself with small pieces of fruit, meat and cheese.

At 7 months. He refused spoon feeding and drank SMA formula from a cup, 60-120 ml twice daily, and continued vigorous breast feeding. Milk from both breasts expressed at to months has been analysed by Mr William Branch of the Dunn Nutritional Laboratory, Cambridge, by courtesy of Dr Elsie Widdowson (Tables $\mathrm{r}, 2$ and 3 ).

Table 1. Chemical composition $(\mid l)$ of human, gorilla and $S M A^{*}$ (artificial) milks

\begin{tabular}{|c|c|c|c|c|c|c|c|}
\hline & \multirow[b]{2}{*}{$\begin{array}{l}\text { Solids } \\
\text { (g) }\end{array}$} & \multirow[b]{2}{*}{$\begin{array}{l}\text { Protein } \\
\text { (g) }\end{array}$} & \multirow[b]{2}{*}{$\begin{array}{l}\text { Lactose } \\
\text { (g) }\end{array}$} & \multirow[b]{2}{*}{$\begin{array}{l}\text { Lipid } \\
(\mathrm{g})\end{array}$} & \multirow[b]{2}{*}{$\begin{array}{c}\text { Ash } \\
\text { (g) }\end{array}$} & \multicolumn{2}{|c|}{$\overbrace{}^{\text {Energy }}$} \\
\hline & & & & & & $(\mathrm{MJ})$ & (kcal) \\
\hline Human & 122 & 12 & 70 & 38 & 2 & $2 \cdot 78$ & 665 \\
\hline Gorilla & 94 & 12 & $7 \mathrm{I}$ & $5 \cdot 2$ & 3 & $I \cdot 5 I$ & $3^{6 \mathrm{I}}$ \\
\hline SMA* & 125 & I5 & 70 & 35 & 5 & 2.67 & 639 \\
\hline
\end{tabular}

*Artificial milk preparation: John Wyeth Ltd, Maidenhead, Berks.

Table 2. Mineral content (mmolll) of human, gorilla and cow's milk

$\begin{array}{lccccc} & \text { Sodium } & \text { Potassium } & \text { Magnesium } & \text { Calcium } & \text { Phosphorus } \\ \text { Human } & 7.5 & 13.3 & 2.0 & 7.0 & 4.5 \\ \text { Gorilla } & 12.3 & 13.6 & 1.7 & 10.0 & 5.6 \\ \text { Cow } & 33.4 & 35.8 & 4.9 & 30.0 & 32.9\end{array}$

Table 3. Fatty acid composition of human and gorilla milk, expressed as a percentage of total fatty acids

\begin{tabular}{lcccc} 
& Saturated & Unsaturated & Oleic & Linoleic \\
Human & $48 \cdot 2$ & $51 \cdot 8$ & $36 \cdot 5$ & $8 \cdot 0$ \\
Gorilla* & $57 \cdot 3$ & $42 \cdot 7$ & $35 \cdot 1$ & $7 \cdot 6$ \\
& \multicolumn{3}{c}{ *Mean of two samples. }
\end{tabular}

Breast-feeding continued regularly until $\mathrm{r}_{7}$ months, then he gradually sucked less frequently and only apparently for comfort. He has not been observed to suck in the daytime since he reached 2 years.

$\mathrm{He}$ is an extremely lively and sturdy animal with good fur, satisfactory dentition and excellent muscle tone. He has had two mild colds and one mild attack of nonspecific gastroenteritis at I year. His weight progress is shown in Fig. I. It has not been possible to estimate haemoglobin but he has no clinical signs of anaemia. Faeces have been regularly examined for parasites and intestinal pathogenic bacteria, and have always been negative. 


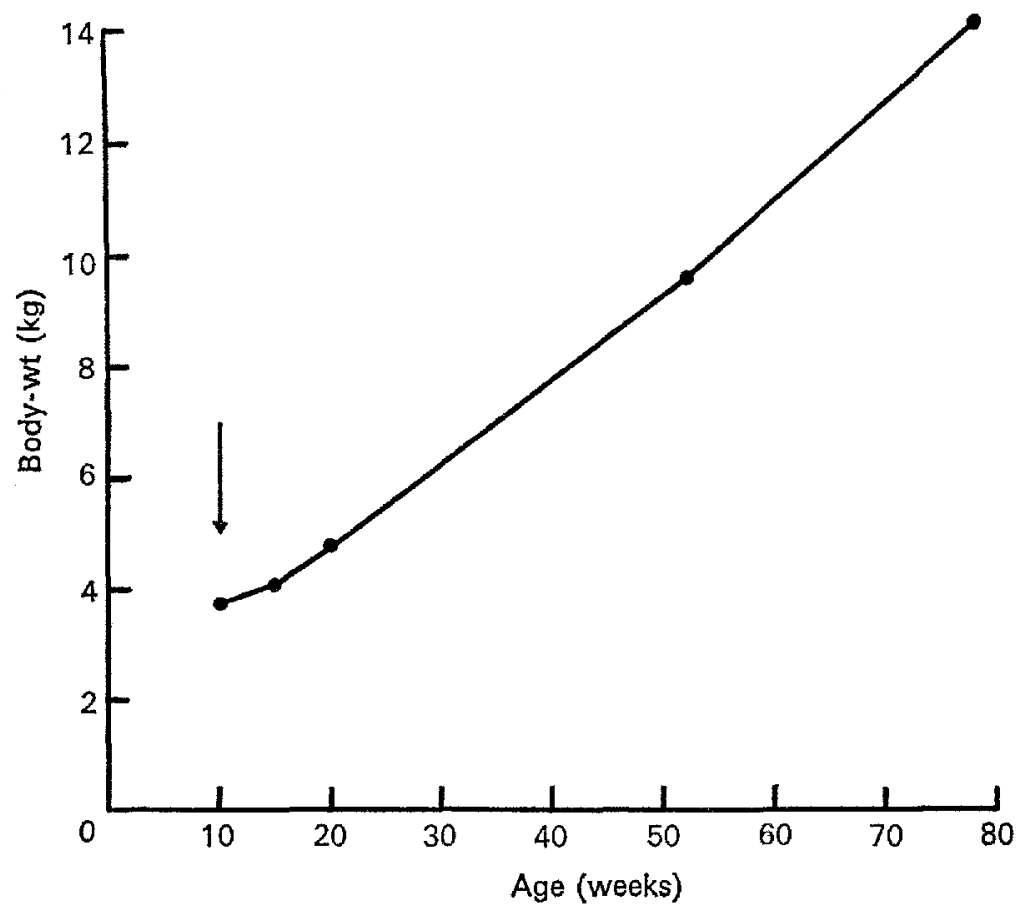

Fig. I. Growth of infant gorilla (Gorilla g. gorilla) from the time $(\downarrow)$ from which breast-feeding was supplemented with other foods.

I am grateful to the Director and the Council of Bristol and Clifton Zoological Society for allowing me to participate in this work. 